\section{AMERICAN-EURASIAN JOURNAL OF SUSTAINABLE AGRICULTURE}

\title{
Analysis of Social Capital to the Local-Striped Buffalo Marketing in Indigenous Tribe of Toraja
}

\author{
A.Erna Mustafa ${ }^{1}$, Arman Reeng $^{1}$, St.Nurani Sirajuddin $^{2}$, Nurdwiana Sari Saudi $^{3}$ \\ 1) Department of Agriculture, Faculty of Agriculture, Muhammadiyah University Pare-Pare \\ 2) Department of socioeconomcs, Faculty of Animal Science, Hasanuddin University of Macassar \\ 3) Department of Management, Faculty of Business Economics, Hasanudin University Of Macassart, South Sulawesi Provice
}

Received date: 12 February 2019, Accepted date: 15 May 2019, Online date: 3 June 2019

Address for Correspondence:

A.Erna Mustafa, Department of Agriculture, Faculty of Agriculture, Muhammadiyah University Pare-Pare

Copyright $\odot 2019$ by authors and American-Eurasian Network for Scientific Information.

This work is licensed under the Creative Commons Attribution International License (CC BY).

http://creativecommons.org/licenses/by/4.0/

\section{(C) (i) Open Access}

\begin{abstract}
This study examined the role of social capital in the marketing of local buffalo (tedong bonga) in the indigenous Toraja tribe, held from April to June of $\mathbf{2 0 1 8}$ at the Bolu Animal Market in North Toraja Regency. The aimed of the study was to determine the role of elements of social capital (norms/customs, beliefs and networks) in marketing buffalo cattle in North Toraja Regency. The research methodology used was purposive sampling method, which is deliberate sampling according to the required criteria, namely all breeders and traders who sell tedong bonga, which are found in the market as many as 21 respondents. This type of research uses quantitative and qualitative data. Quantitative data is calculated using the Likert scale to see the level of social capital towards marketing tedong bonga while qualitative information is used to describe the role of elements of social capital towards marketing tedong bonga. The results showed that in the norm variable, the dominant indicator was rules, sanctions, and behavior, in the trust variable, the dominant indicator was honesty and fairness, while in the social network variable, the dominant indicator was social concern and cooperation. The total overall value shows the level of social capital greatly influences the marketing of tedong bonga. Based on these results the recommendations that can be given are that local governments can manage social capital as a social and cultural asset to improve the lives of Toraja people in particular and the development of Toraja regions through the livestock and tourism sectors in general.

KEYWORDS

social capital, buffalo, local striped
\end{abstract}

\section{INTRODUCTION}

Buffalo is an animal that plays a large role for the indigenous tribe of Toraja. It is caused by relationship with culture and customs of the local community. Buffalo for indigenous tribe of Toraja tribe is not only a pet but has a much higher social function, namely as a sacrificial animal in traditional rituals, a symbol of one's prosperity and social status when carrying out a traditional party [1]. Even though the development of the world is progressing, indigenous tribes of Toraja still hold tightly to their ancestral culture.

The function of buffalo in this area can replace the physical value of money as an exchange tool. Land and rice sales/pledges and even marriage dowries are still based on the number of buffaloes. This is by the opinion of [2] that buffaloes are a social symbol for their owners in several tribes in Indonesia. Social capital holds a very important role in strengthening the lives of modern society. Various problems in various countries are due to the lack of social capital that grow in the midst of society which has the effect of dimming the spirit of mutual cooperation, exacerbating poverty and obstructing efforts to improve the welfare of the population. Social 
A.Erna Mustafa et al., 2019. Analysis of Social Capital to the Local-Striped Buffalo Marketing in Indigenous Tribe of Toraja /American-Eurasian Journal of Sustainable Agriculture. 13(2): 92-99. DOI: 10.22587/aejsa.2019.13.2.11

capital is a condition that must be met for human development, economic development, social, political and democratic stability [3] and [4] Striped buffalo that is called "tedong bonga", a local buffalo of indigenous tribe of Toraja, which is a prima donna compared to other buffaloes. This is because the characteristics of its body is quite unique on its social function in indigenous tribe of Toraja. The more beautiful the buffalo, the more expensive the price and the higher social level of the owner as well. The existence of tedong bonga in Toraja is very limited in number. Various ways are done to increase the population but often fail, so to get it, the buffalo traders take it from other regencies even outside of South Sulawesi Province.

Toraja Regency is the region that has the most buffalo population in South Sulawesi Province. This is because of the culture and customs so that the entry of buffalos from the various areas to this area is quite high.

Table 1. Data on Buffalo in Several Regencies in South Sulawesi for the Last Five Years

\begin{tabular}{|c|c|c|c|c|c|c|}
\hline \multirow{2}{*}{ Number } & \multirow{2}{*}{ Regency } & \multicolumn{5}{|l|}{ Year } \\
\hline & & 2013 & 2014 & 2015 & 2016 & 2017 \\
\hline 1 & Selayar Island & 4,460 & 4,514 & 4,588 & 4,674 & 4,684 \\
\hline 2 & Bulukumba & 1,529 & 1,548 & 1,570 & 1,588 & 1,619 \\
\hline 3 & Bantaeng & 203 & 194 & 172 & 177 & 83 \\
\hline 4 & Jeneponto & 3,310 & 3,597 & 3,759 & 3,860 & 3,937 \\
\hline 5 & Takalar & 3,235 & 3,271 & 2,935 & 3,319 & 3,109 \\
\hline 6 & Gowa & 1,468 & 1,537 & 1,670 & 1,607 & 1,388 \\
\hline 7 & Sinjai & 1,127 & 1,202 & 1,233 & 1,108 & 1,134 \\
\hline 8 & Bone & 3,841 & 3,955 & 4,075 & 4,198 & 4,505 \\
\hline 9 & Maros & 2,634 & 2,950 & 3,332 & 3,818 & 4,330 \\
\hline 10 & Pangkep & 3,068 & 3,183 & 3,288 & 3,423 & 3,141 \\
\hline 11 & Barru & 707 & 834 & 839 & 720 & 699 \\
\hline 12 & Soppeng & 75 & 105 & 91 & 46 & 69 \\
\hline 13 & Wajo & 3,917 & 5,949 & 5,960 & 6,969 & 6,212 \\
\hline 14 & Sidrap & 2,569 & 2,711 & 2,853 & 3,004 & 3,158 \\
\hline 15 & Pinrang & 2,599 & 2,939 & 3,231 & 3,500 & 3,397 \\
\hline 16 & Enrekang & 3,271 & 3,167 & 3,414 & 3,730 & 3,744 \\
\hline 17 & Tana Toraja & 22,448 & 25,416 & 25,553 & 26,026 & 26,094 \\
\hline 18 & Palopo & 453 & 496 & 498 & 489 & 486 \\
\hline 19 & Luwu & 5.871 & 5.754 & 5,665 & 5,799 & 5,567 \\
\hline 20 & North Luwu & 12.117 & 13.323 & 14,218 & 14,929 & 15,380 \\
\hline 21 & East Luwu & 1,021 & 1,041 & 1,043 & 1,094 & 1,067 \\
\hline 22 & Makasar & 398 & 386 & 366 & 301 & 274 \\
\hline 23 & Pare-Pare & 91 & 25 & 72 & 68 & 65 \\
\hline \multirow[t]{2}{*}{24} & North Toraja & 20,419 & 20,582 & 18,121 & 21,002 & 20,731 \\
\hline & Total & 100,831 & 108,679 & 108,546 & 115,449 & 114,837 \\
\hline
\end{tabular}

Source: South Sulawesi Provincial Livestock Service, 2018

Based on Table 1, it can be seen that the largest buffalo population is in the region inhabited by the Toraja tribes; these are Tana Toraja and North Toraja Regency. In North Toraja, the number of buffalo population in 2013 was 20,419. It increased in 2014 to 20,582 but decreased in 2015 to 18, 12 in 2016; it increased dramatically to 21,002. The latest data obtained by the population decreased again in 2017 to 20,731[5]

Compared to other regencies, buffalo population in Toraja tend to increase because the level of buffalo cuts every year rises along with the increasing economic life of North Toraja people who live overseas, so when they go home, they will cut a lot of buffaloes. The high price of buffalo in the two regencies inhabited by the 
A.Erna Mustafa et al., 2019. Analysis of Social Capital to the Local-Striped Buffalo Marketing in Indigenous Tribe of Toraja /American-Eurasian Journal of Sustainable Agriculture. 13(2): 92-99. DOI: 10.22587/aejsa.2019.13.2.11

indigenous tribe of Toraja made buffalo farmers and traders from other regencies interested in coming to Toraja to sell their buffalo in the hope of getting high profit [6]

Most of buffalo cuts in North Toraja Regency were done for the needs of traditional party, the number reaches thousands of heads per year. While the buffalo that is cut in slaughter house for sale is only tens of buffaloes per year. Data on buffalo cutting can be seen in Figure 1.

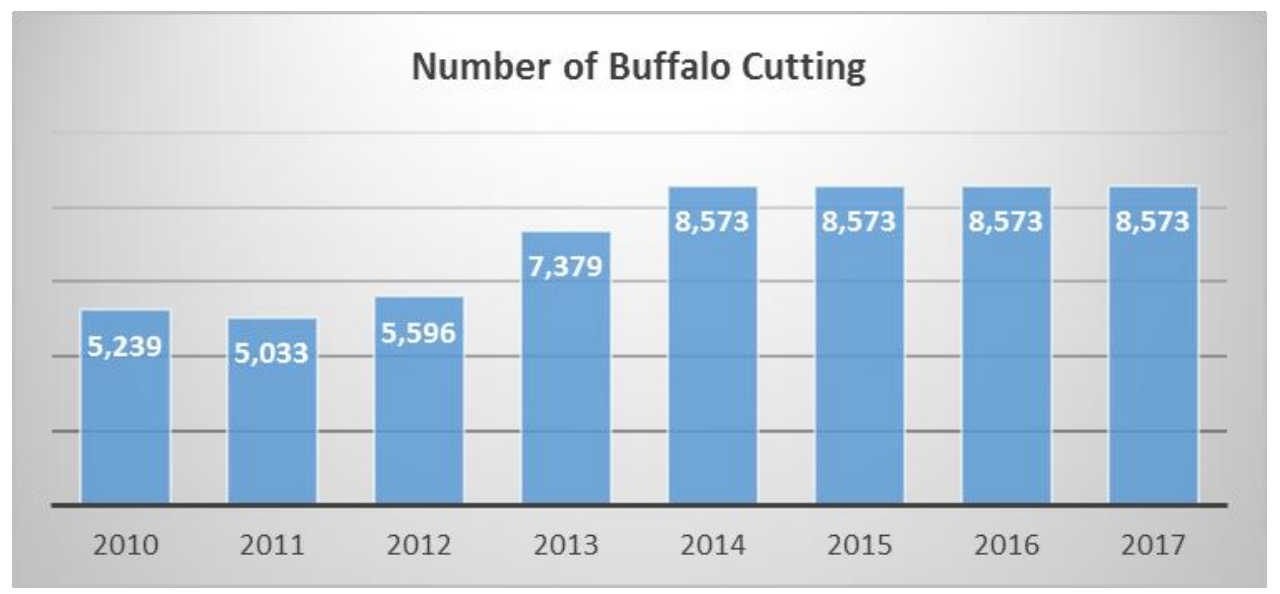

Figure 1. Data on Buffalo Cutting in North Toraja for the Last Seven Years

Figure 1 showed that the needs of buffaloes for indigenous tribe of Toraja were quite high. The welfare of the people was getting better until the existence of culture and customs were always maintained even though the changing times and the mindset continued to change does not diminish the spirit to love and support the traditions of their ancestors.

\section{Research of Method}

This research was carried out from April to June 2018 at Bolu Animal Market in North Toraja. This location was chosen intentionally because Bolu Animal Market is a center for buying and selling buffalos where all breeders and traders who want to purchase and selling transactions gather in this place either on market days or not market days. Bolu Animal Market is one and only animal market in the world which only sells buffalo and pig in large enough quantities to thousands, making it a destination for both domestic and international tourists. Type of research is descriptive quantitative. Population in this study were all breeders and local-striped buffalo traders while sample were all breeders and local-striped buffalo traders who found in Bonga Animal Market both on market days and not market days.

Analysis of the data used was descriptive statistics using data grouping and presentation using likert scale.

\section{Results and Discussion}

\section{Norms}

Table 3. Measurement of Social Capital in Norms Sub-Variables on Respondents of Breeders

\begin{tabular}{|c|c|c|c|c|c|c|}
\hline Number & Indicators & Categories & Score & $\begin{array}{l}\text { Frequency } \\
\text { (Person) }\end{array}$ & Total & Percentage \\
\hline \multirow[t]{4}{*}{1} & Rule & Very important & 3 & 12 & 36 & 100 \\
\hline & & Normal & 2 & & 0 & \\
\hline & & Not important & 1 & & 0 & \\
\hline & & Total & & & 36 & \\
\hline \multirow[t]{4}{*}{2} & Sanction & Very important & 3 & 12 & 36 & 100 \\
\hline & & Normal & 2 & & 0 & \\
\hline & & Not important & 1 & & 0 & \\
\hline & & Total & & & 36 & \\
\hline \multirow[t]{3}{*}{3} & Behavior & Very important & 3 & 12 & 36 & 100 \\
\hline & & Normal & 2 & & 0 & \\
\hline & & Not important & 1 & & 0 & \\
\hline
\end{tabular}


A.Erna Mustafa et al., 2019. Analysis of Social Capital to the Local-Striped Buffalo Marketing in Indigenous Tribe of Toraja /American-Eurasian Journal of Sustainable Agriculture. 13(2): 92-99. DOI: 10.22587/aejsa.2019.13.2.11

\begin{tabular}{|c|c|c|c|c|c|c|}
\hline & & Total & & 12 & 36 & \\
\hline \multirow[t]{4}{*}{4} & Payment system & Very important & 3 & 6 & 18 & 75 \\
\hline & & Normal & 2 & & 6 & \\
\hline & & Not important & 1 & 6 & 6 & 25 \\
\hline & & Total & & 12 & 30 & 100 \\
\hline \multirow[t]{4}{*}{5} & $\begin{array}{l}\text { Mutual } \\
\text { cooperation }\end{array}$ & Very important & 3 & 12 & 36 & 100 \\
\hline & & Normal & 2 & & 0 & \\
\hline & & Not important & 1 & & 0 & \\
\hline & & Total & & & 36 & \\
\hline
\end{tabular}

Likert scale for very important $=3$; normal $=2$; not important $=1$

Based on Table 3, it can be seen that the answer of the breeder respondents for sub-variables of norm in four indicators; rule, sanction, behavior and mutual cooperation had a perfect value that was 36 . In the sale and purchase of buffalo, the Indigenous Tribe of Toraja applied the term buffalo lending and borrowing. This term meant giving buffalo to traders or people who needed it and the payment was made later. This aims to help Indigenous Tribe of Toraja carried out the ceremonial death of their families without being hampered by the price of buffalo. The condition adhered to an attitude that was very guarded by the Indigenous Tribe of Toraja, in this case helping or mutual cooperation.

Before borrowing or lending was done, the breeders would see the personal background and the borrower's family whether they were trustworthy or not. This buying and selling system was still relatively traditional because there was no agreement written in it, but breeders really appreciate the rules and sanctions were made by both. The rules and witnesses such as payment time agreement to the late payment penalty.

Table 4. Measurement of Social Capital in Norm Sub-Variables on Respondent of Traders

\begin{tabular}{|c|c|c|c|c|c|c|}
\hline Number & Indicators & Categories & Score & $\begin{array}{l}\text { Frequency } \\
\text { (Person) }\end{array}$ & Total & Percentage \\
\hline \multirow[t]{4}{*}{1} & Openness & Very important & 3 & 9 & 27 & 100 \\
\hline & & Normal & 2 & & 0 & \\
\hline & & Not important & 1 & & 0 & \\
\hline & & Subtotal & & & 27 & \\
\hline \multirow[t]{4}{*}{2} & Honesty & Very important & 3 & 9 & 27 & 100 \\
\hline & & Normal & 2 & & 0 & \\
\hline & & Not important & 1 & & 0 & \\
\hline & & Subtotal & & & 27 & \\
\hline \multirow[t]{4}{*}{3} & Commitment & Very important & 3 & 9 & 27 & 100 \\
\hline & & Normal & 2 & & 0 & \\
\hline & & Not important & 1 & & 0 & \\
\hline & & Subtotal & & & 27 & \\
\hline \multirow[t]{4}{*}{4} & Fairy & Very important & 3 & 2 & 6 & 37.5 \\
\hline & & Normal & 2 & 3 & 6 & 37.5 \\
\hline & & Not important & 1 & 4 & 4 & 25 \\
\hline & & Subtotal & & 9 & 16 & 100 \\
\hline \multirow[t]{5}{*}{5} & Solidarity & Very important & 3 & 9 & 27 & 100 \\
\hline & & Normal & 2 & & 0 & \\
\hline & & Not important & 1 & & 0 & \\
\hline & & Subtotal & & & 27 & \\
\hline & & Total & & & 124 & \\
\hline
\end{tabular}

Likert scale for very important=3; normal=2; not important=1 
A.Erna Mustafa et al., 2019. Analysis of Social Capital to the Local-Striped Buffalo Marketing in Indigenous Tribe of Toraja /American-Eurasian Journal of Sustainable Agriculture. 13(2): 92-99. DOI: 10.22587/aejsa.2019.13.2.11

Based on Table 4, it can be seen that the respondent's answer to the sub variables of norm in four indicators; rules, sanctions, behavior and mutual cooperation also had a perfect value of $100 \%$. Although traders seek profits in buying and selling buffalo, they still maintain the culture of the Indigenous Tribes of Toraja which was to preserve mutual cooperation and help to help the Indigenous Tribes of Toraja's death party by lending buffalo. Even so buffalo borrowing from traders was also accompanied by clear rules and strict enforcement of sanctions such as taking borrowers' assets that are equivalent to the price of buffalo agreed at the beginning. Therefore, before borrowing was done, it was important to know the behavior and background of the borrowers.

2. Trusts

One of the elements of social capital needed in the group is the nature and attitude to trust and trustworthy in the relationship so that among the group members have a high level of trust. Trust is a very important capital to build a network Veronica et al,2017

Table 5. Measurement of Social Capital in Trusts Sub-Variables on Respondent of Breeders

\begin{tabular}{|c|c|c|c|c|c|c|}
\hline Number & Indicators & Categories & Score & $\begin{array}{l}\text { Frequency } \\
\text { (Person) }\end{array}$ & Total & Percentage \\
\hline \multirow[t]{4}{*}{1} & Openness & Very important & 3 & 9 & 27 & 84.38 \\
\hline & & Normal & 2 & 2 & 4 & 12.50 \\
\hline & & Not important & 1 & 1 & 1 & 3.13 \\
\hline & & Subtotal & & 12 & 32 & 100 \\
\hline \multirow[t]{4}{*}{2} & Honesty & Very important & 3 & 12 & 36 & 100 \\
\hline & & Normal & 2 & 0 & 0 & 0 \\
\hline & & Not important & 1 & 0 & 0 & 0 \\
\hline & & Subtotal & & 12 & 36 & 100 \\
\hline \multirow[t]{4}{*}{3} & Commitment & Very important & 3 & 11 & 33 & 97.06 \\
\hline & & Normal & 2 & 0 & 0 & 0 \\
\hline & & Not important & 1 & 1 & 1 & 2.94 \\
\hline & & Subtotal & & 12 & 34 & 100 \\
\hline \multirow[t]{4}{*}{4} & Fairness & Very important & 3 & 12 & 36 & 100 \\
\hline & & Normal & 2 & 0 & 0 & 0 \\
\hline & & Not important & 1 & & 0 & 0 \\
\hline & & Subtotal & & 12 & 36 & 100 \\
\hline \multirow[t]{5}{*}{5} & Solidarity & Very important & 3 & 3 & 9 & 39.13 \\
\hline & & Normal & 2 & 5 & 10 & 43.48 \\
\hline & & Not important & 1 & 4 & 4 & 17.39 \\
\hline & & Subtotal & & 12 & 23 & 100 \\
\hline & & Total & & & 161 & \\
\hline
\end{tabular}

Likert scale for very important=3; normal=2; not important=1

Based on Table 5, it can be seen that the answer of the breeder respondents to the highest score in sub-variable of trusts of honesty and fairness indicators were $100 \%$. Breeders really appreciated honesty in buying and selling transactions. If the borrower is able to maintain trust. Buying and selling relationship will long last, so the borrower often got a long payment time for up to a year. Besides that, a fair profit sharing would be added to the value of trust, so that the breeders felt that they were treated well by the borrowers.

Table 6. Measurement of Social Capital in Trusts Sub-Variables on Respondent of Traders

\begin{tabular}{lllllll}
\hline \multirow{2}{*}{ Number } & Indicators & Categories & Score & $\begin{array}{l}\text { Frequency } \\
\text { (Person) }\end{array}$ & Total & Percentage \\
\hline 1 & Openness & Very important & 3 & 4 & 12 & 63.16 \\
& & Normal & 2 & 2 & 4 & 21.05 \\
& & Not important & 1 & 3 & 3 & 15.79 \\
& & Subtotal & & $\mathbf{9}$ & $\mathbf{1 9}$ & 100 \\
\hline
\end{tabular}


A.Erna Mustafa et al., 2019. Analysis of Social Capital to the Local-Striped Buffalo Marketing in Indigenous Tribe of Toraja /American-Eurasian Journal of Sustainable Agriculture. 13(2): 92-99. DOI: 10.22587/aejsa.2019.13.2.11

\begin{tabular}{|c|c|c|c|c|c|c|}
\hline \multirow[t]{4}{*}{2} & Honesty & Very important & 3 & 9 & 27 & 100 \\
\hline & & Normal & 2 & 0 & 0 & 0 \\
\hline & & Not important & 1 & 0 & 0 & 0 \\
\hline & & Subtotal & & 9 & 27 & 100 \\
\hline \multirow[t]{4}{*}{3} & Commitment & Very important & 3 & 8 & 24 & 96 \\
\hline & & Normal & 2 & 0 & 0 & 0 \\
\hline & & Not important & 1 & 1 & 1 & 4 \\
\hline & & Subtotal & & 9 & 25 & 100 \\
\hline \multirow[t]{4}{*}{4} & Fairness & Very important & 3 & 9 & 27 & 100 \\
\hline & & Normal & 2 & 0 & 0 & 0 \\
\hline & & Not important & 1 & 0 & 0 & 0 \\
\hline & & Subtotal & & 9 & 27 & 100 \\
\hline \multirow[t]{5}{*}{5} & Solidarity & Very important & 3 & 0 & 0 & 0 \\
\hline & & Normal & 2 & 2 & 4 & 36.36 \\
\hline & & Not important & 1 & 7 & 7 & 63.64 \\
\hline & & Subtotal & & 9 & 11 & 100 \\
\hline & & Total & & & 109 & \\
\hline
\end{tabular}

\footnotetext{
Likert scale for very important $=3$; normal=2; not important $=1$
}

Based on Table 6, it was known that the respondent's answers to the highest score of trust sub-variables were also in the honesty and fairness indicators. Honesty factor in buying and selling transactions such as telling the origin of buffalo, the price of buffalo before, the purpose of borrowing buffalo would make that traders felt valued, so that they would build a long time cooperation. While fairness was like the distribution of benefits that were appropriate if between traders help each other such as giving information or helping to find buffaloes whose characteristics are desired by consumers.

\section{Social Networks}

Table 7. Measurement of Social Capital in Social Networks Sub-Variables on Respondent of Breeders

\begin{tabular}{|c|c|c|c|c|c|c|}
\hline Number & Indicators & Categories & Score & $\begin{array}{l}\text { Frequency } \\
\text { (Person) }\end{array}$ & Total & Percentage \\
\hline \multirow[t]{4}{*}{1} & \multirow[t]{4}{*}{ Social networks } & Very important & 3 & 3 & 9 & 37.50 \\
\hline & & Normal & 2 & 6 & 12 & 50.00 \\
\hline & & Not important & 1 & 3 & 3 & 12.50 \\
\hline & & Subtotal & & 12 & 24 & 100 \\
\hline \multirow[t]{4}{*}{2} & \multirow[t]{4}{*}{ Cooperation } & Very important & 3 & 11 & 33 & 97.06 \\
\hline & & Normal & 2 & 0 & 0 & 0 \\
\hline & & Not important & 1 & 1 & 1 & 2.94 \\
\hline & & Subtotal & & 12 & 34 & 100 \\
\hline \multirow[t]{4}{*}{3} & \multirow[t]{4}{*}{$\begin{array}{l}\text { Similarity of } \\
\text { Tribe }\end{array}$} & Very important & 3 & 2 & 6 & 25.00 \\
\hline & & Normal & 2 & 8 & 16 & 66.67 \\
\hline & & Not important & 1 & 2 & 2 & 8.33 \\
\hline & & Subtotal & & 12 & 24 & 100 \\
\hline \multirow[t]{4}{*}{4} & \multirow[t]{4}{*}{ Mutual helping } & Very important & 3 & 11 & 33 & 97.06 \\
\hline & & Normal & 2 & 0 & 0 & 0 \\
\hline & & Not important & 1 & 1 & 1 & 2.94 \\
\hline & & Subtotal & & 12 & 34 & 100 \\
\hline \multirow[t]{2}{*}{5} & \multirow[t]{2}{*}{ Social caring } & Very important & 3 & 12 & 36 & 100 \\
\hline & & Normal & 2 & 0 & 0 & 0 \\
\hline
\end{tabular}


A.Erna Mustafa et al., 2019. Analysis of Social Capital to the Local-Striped Buffalo Marketing in Indigenous Tribe of Toraja /American-Eurasian Journal of Sustainable Agriculture. 13(2): 92-99. DOI: 10.22587/aejsa.2019.13.2.11

\begin{tabular}{lllll} 
Not important & 1 & 0 & 0 & 0 \\
$\begin{array}{l}\text { Subtotal } \\
\text { Total }\end{array}$ & & $\mathbf{1 2}$ & $\mathbf{3 6}$ & $\mathbf{1 0 0}$ \\
\hline normal & & & $\mathbf{1 5 2}$ &
\end{tabular}

Likert scale for very important=3; normal=2; not important $=1$

Based on Table 7, it was known that the answers of the breeder respondents to the social network sub variables which were the highest score was on the indicators of social caring. The culture of helping, especially for the preparation of the traditional party, had become the character of the Indigenous Tribe of Toraja. So that, their social caring between each other was so high. Social caring was shown through building cooperation such as building lantang-lantang, donating food, money and buffalo as well to help the death party. It was because the need to have a party was quite large and lots of costs, they often borrowed buffalo from breeders with a payment agreement after the party was finished. Breeders who already knew the family background will lend their buffalo with an agreement.

Table 8. Measurement of Social Capital in Social Networks Sub-Variables on Respondent of Traders

\begin{tabular}{|c|c|c|c|c|c|c|}
\hline Number & Indicators & Categories & Score & $\begin{array}{l}\text { Frequency } \\
\text { (Person) }\end{array}$ & Total & Percentage \\
\hline \multirow[t]{4}{*}{1} & \multirow[t]{4}{*}{ Social networks } & Very important & 3 & 0 & 0 & 0 \\
\hline & & Normal & 2 & 1 & 2 & 20 \\
\hline & & Not important & 1 & 8 & 8 & 80 \\
\hline & & Subtotal & & 9 & 10 & 100 \\
\hline \multirow[t]{4}{*}{2} & \multirow[t]{4}{*}{ Cooperation } & Very important & 3 & 9 & 27 & 100 \\
\hline & & Normal & 2 & 0 & 0 & 0 \\
\hline & & Not important & 1 & 0 & 0 & 0 \\
\hline & & Subtotal & & 9 & 27 & 100 \\
\hline \multirow[t]{4}{*}{3} & \multirow[t]{4}{*}{$\begin{array}{l}\text { Similarity of } \\
\text { Tribe }\end{array}$} & Very important & 3 & 0 & 0 & 0 \\
\hline & & Normal & 2 & 4 & 8 & 61.53 \\
\hline & & Not important & 1 & 5 & 5 & 38.46 \\
\hline & & Subtotal & & 9 & 13 & 100 \\
\hline \multirow[t]{4}{*}{4} & \multirow[t]{4}{*}{ Mutual helping } & Very important & 3 & 8 & 24 & 96 \\
\hline & & Normal & 2 & 0 & 0 & 0 \\
\hline & & Not important & 1 & 1 & 1 & 4 \\
\hline & & Subtotal & & 9 & 25 & 100 \\
\hline \multirow[t]{5}{*}{5} & \multirow[t]{5}{*}{ Social caring } & Very important & 3 & 9 & 27 & 100 \\
\hline & & Normal & 2 & 0 & 0 & 0 \\
\hline & & Not important & 1 & 0 & 0 & 0 \\
\hline & & Subtotal & & 9 & 27 & 100 \\
\hline & & Total & & & 102 & \\
\hline
\end{tabular}

Likert scale for very important=3; normal=2; not important=1

Based on Table 8, it was known that the answers of trader' respondents to the social network sub-variables, the highest score were on the indicators of cooperation and social caring. Even though traders need capital to buy and sell buffalo, they were willing to lend their buffalo but with a payment time that was not too long. This was a form of social caring between Indigenous Tribe of Toraja.

4. Total Score of Social Capital

Total score of social capital as a whole can be seen in Table 9 below:

Table 9. Total Score of Social Capital for Breeders and Traders

\begin{tabular}{llll}
\hline Variable & Sub-Variables & Score & Kategory \\
\hline \multirow{2}{*}{ Social capital } & & & \\
& Norms & 292 & High \\
& Trusts & 272 & High
\end{tabular}


A.Erna Mustafa et al., 2019. Analysis of Social Capital to the Local-Striped Buffalo Marketing in Indigenous Tribe of Toraja /American-Eurasian Journal of Sustainable Agriculture. 13(2): 92-99. DOI: 10.22587/aejsa.2019.13.2.11

\begin{tabular}{llll}
\hline & Social Networks & 254 & High \\
\cline { 2 - 4 } & Total & $\mathbf{8 1 8}$ & High \\
\hline
\end{tabular}

Table 9 showed that overall score of social capital in both breeders and traders obtained 818 results in high category. This showed that the role of social capital for the marketing of local-striped buffalo (tedong bonga) in Indigenous Tribe of Toraja was quite high. This is accordance with [7] opinion which stated that the higher social capital, the positive correlation with income and business economy.

\section{I.4. Conclusions}

The role of social capital towards the marketing of local-striped buffalo (tedong bonga) was very influential. It can be seen from the value of each sub variable which was norms, trusts and social networks had high scores and categories. The high role of social capital had a significant influence on the overall social, economic and cultural development of Toraja. From the social side, the brotherhood of Indigenous Tribe of Toraja was increasingly visible from the existence of cooperation, mutual helping and high social caring. In economic standpoint, borrowing and lending buffaloes made people who did not have capital can be economically empowered and in terms of the culture of death party that was popularly called rambu solo. It became the hallmark of Indigenous Tribe of Toraja which could be tourist attraction. So that, it had a direct impact on people's lives in particularly and development of Toraja Regency generally.

\section{ACKNOWLEDGEMENT}

The author would like to thank to the Ministry of Research, Technology and Higher Education of Indonesia for funding of this research.

\section{REFERENCES}

[1] Patty. J.H.I. 2008. Buffalo As a Symbol of Social Status In The Solo Sign Tradition. Journal Filsafat.

[2]Bamuallim, A, Muhammad Z, Talib C. 2008. The Role And Availability Of Buffalo Development Technology In Indonesia. Puslitbang Peternakan. Bogor.

[3] Fukuyama F. 1995.Trust: The Social Virtue And The Creation Of Properity. New York Free Press.

[4] S N Sirajuddin, A R Siregar and P Mappigau..2018. Application of capital social of Bali cattle farmers that participate in the partnership system in Barru Regency, South Sulawesi Province. IOP Conf. Series: Earth and Environmental Science 157012059 doi :10.1088/17551315/ 157/1/012059

[5]Department of Animal Husbandry. Population Data And Cutting Buffalo Livestock. Province South Sulawesi. 2018

[6] Erna Mustafa.Arman,Sitti Nurani Siarajuddin,Nurdiana Sari Saudi.2019.Social status relationship to purchase

[7] Mustafa, of tedong bonga for the community Toraja tribes. $1^{\text {st }}$ international conference of animal science and Technology(ICAST).IOP Conf:Earth and Enviromental

[8] .Veronica Sri Lestari, Sitti Nurani Sirajuddin, Agustina Abdullah.2017. Identification of Social Capital on Beef Cattle Farmer Group .Advances in Environmental Biology, 11(11) November 2017, Pages: 6-10 